University of Nebraska - Lincoln

DigitalCommons@University of Nebraska - Lincoln

Uniformed Services University of the Health

Sciences

U.S. Department of Defense

1986

\title{
Production of Shiga-Like Toxin by Escherichia coli
}

Lilian R. M. Marques

Uniformed Services University of the Health Sciences

Marjorie A. Moore

Uniformed Services University of the Health Sciences

Joy G. Wells

Uniformed Services University of the Health Sciences

I. Kate Wachsmuth

Uniformed Services University of the Health Sciences

Alison D. O'Brien

Uniformed Services University of the Health Sciences, alison.obrien@usuhs.edu

Follow this and additional works at: https://digitalcommons.unl.edu/usuhs

Part of the Medicine and Health Sciences Commons

Marques, Lilian R. M.; Moore, Marjorie A.; Wells, Joy G.; Wachsmuth, I. Kate; and O'Brien, Alison D., "Production of Shiga-Like Toxin by Escherichia coli" (1986). Uniformed Services University of the Health Sciences. 112.

https://digitalcommons.unl.edu/usuhs/112

This Article is brought to you for free and open access by the U.S. Department of Defense at DigitalCommons@University of Nebraska - Lincoln. It has been accepted for inclusion in Uniformed Services University of the Health Sciences by an authorized administrator of DigitalCommons@University of Nebraska Lincoln. 


\section{Production of Shiga-Like Toxin by Escherichia coli}

Escherichia coli is one of several agents that cause intestinal disease in humans and animals. Four classes of $E$. coli have been recognized [1]. Enterotoxigenic $E$. coli $($ ETEC) strains produce a heat-labile (LT) enterotoxin and/or a heat-stable (ST) enterotoxin. Enteroinvasive E. coli (EIEC) strains, like shigellae, penetrate and multiply within epithelial cells. Enteropathogenic $E$. coli (EPEC) strains belong to certain serogroups that have been incriminated as pathogens by epidemiological studies. Some EPEC strains have been shown to adhere to cells of the intestinal mucosa and to produce pathognomonic lesions at the site of attachment. Enterohemorrhagic E. coli (EHEC) strains cause a distinct clinical syndrome (hemorrhagic colitis), and serotype O157:H7 has been associated with this illness. Neither EPEC nor EHEC strains produce classic enterotoxins, nor are they enteroinvasive.

Some strains of $E$. coli produce a cell-associated cytotoxin that is neutralized by antibodies against purified Shiga toxin from Shigella dysenteriae type 1 [2-4]. The cytotoxins purified from one EPEC strain O26:H11 (H30) and from one EHEC strain O157:H7 (933) have biologic activities (cytotoxicity for HeLa and Vero cells, lethality for mice, and enterotoxicity for ligated ileal segments from rabbits) and subunit structures similar to those of Shiga toxin $[5,6]$. The purpose of this study was to determine the frequency and levels of cytotoxin production for a wide variety of $E$. coli strains. Culture supernatants and sonic lysates of 418 strains isolated from humans, animals, and food were examined for cytotoxic effects on HeLa cells and to see whether cytotoxicity could be neutralized by antibodies to Shiga toxin.

\section{Materials and Methods}

Bacterial strains. E. coli strains examined for production of Shiga-like toxin were obtained mainly from the Centers for Disease Control, Atlanta, Georgia. The 418 strains were isolated over a period of 30 years from the following: humans with diarrhea, hemorrhagic colitis, hemolytic uremic syndrome, or no clinical manifestation of disease; calves with diarrhea; piglets with edema dis-

Received for publication 26 November 1985, and in revised form 19 February 1986.

The opinions or assertions contained herein are the private ones of the authors and are not to be construed as official or reflecting the views of the Department of Defense or the Uniformed Services University of the Health Sciences.

This work was supported by grant 2210-00 from the Agency for International Development.

Please address requests for reprints to Dr. Alison D. O'Brien, Department of Microbiology, U.S.U.H.S, 4301 Jones Bridge Road, Bethesda, Maryland 20814-4799. ease; or food. A total of 162 strains belonged to EPEC serogroups O26, O44, O55, O86, O111, O119, O125, O126, $\mathrm{O} 127, \mathrm{O} 128$, and $\mathrm{O} 142$ [7] and were mainly outbreak isolates. Nine strains had been characterized as ETEC by Y-1 adrenal cell assay (for LT) or infant mouse assay (for ST), and 10 strains were characterized as EIEC by the Séreny test. Nineteen strains belonged to serotype O157:H7 and were EHEC. A total of 214 strains did not belong to EPEC serogroups, were not ETEC or EIEC, were not EHEC $\mathrm{O} 157: \mathrm{H} 7$, had no serological data available (strains isolated from healthy humans), or had not been assayed for enterotoxins and invasiveness. Four substrains of $E$. coli $\mathrm{K} 12$ (C600, 395-1, HB101, and K175) were also examined for production of Shiga-like toxin. Strains were stored at $-70 \mathrm{C}$ or lyophilized.

Preparation of bacterial lysates. The strains were cultured in $500 \mathrm{ml}$ of Chelex-treated syncase broth as previously described [2]. The bacteria were harvested by centrifugation [2], and an aliquot of the culture supernatants was collected, filter-sterilized, and stored at $-20 \mathrm{C}$. The bacterial cells were then washed twice in $0.85 \% \mathrm{NaCl}$ and resuspended in a volume of PBS ( $\mathrm{pH} 7.4$ ) equivalent to their wet weight. Samples $(3 \mathrm{ml})$ of the bacterial suspensions were mixed with $2 \mathrm{ml}$ of PBS and sonicated as previously described [8]. The sonic lysates were clarified by centrifugation $(8,000 \mathrm{~g}$ for $1 \mathrm{hr}$ at $4 \mathrm{C})$, filter-sterilized, and stored at $-20 \mathrm{C}$. The protein content of the bacterial lysates was estimated spectrophotometrically [9].

Cytotoxicity assays and toxin neutralization tests. Cytotoxicity assays were performed with HeLa cells by the method of Gentry and Dalrymple [10]. Serial twofold dilutions $(1: 2$ to $1: 64)$ of culture supernatants or sonic lysates were tested, and the cytotoxic dose required to kill $50 \%$ of HeLa cells $\left(\mathrm{CD}_{50}\right)$ was estimated by microscopic examination of the HeLa cells. If $>50 \%$ of the HeLa cells were killed at a 1:64 dilution of a sample, 10-fold serial dilutions of this sample were tested. Cytotoxic titers were expressed as the reciprocal of the $\mathrm{CD}_{50} /$ milliliter of culture supernatant or sonic lysate and as per milligram of sonic lysate protein.

Initially, neutralization assays were done on sonic lysates that had been previously frozen and thawed. However, this procedure eliminated the low-level activity of some lysates. When this problem became apparent, neutralization assays were accomplished at the same time as the cytotoxicity assays by mixing serial dilutions of the lysates with a final 1:100 dilution of rabbit antibody to Shiga toxin or preimmune rabbit serum. The remaining steps were performed as described [2]. Neutralization assays were also done on 10 -fold serial dilutions of cytotoxic culture supernatants. The neutralizing titer of the rabbit antibody to Shiga toxin for $10 \mathrm{CD}_{50}$ of $S$. dysenteriae 1 strain $60 \mathrm{R}$ and $E$. coli strain $\mathrm{H} 30$ preparations was $1: 1,600$. 


\section{Results}

Levels of cytotoxin produced by E. coli. By comparing the cytotoxic titers of lysates expressed as $\mathrm{CD}_{50} / \mathrm{ml}$ and $\mathrm{CD}_{50} / \mathrm{mg}$ of protein, we found that more reproducible results were obtained for some strains with the $C_{50} / \mathrm{ml}$ parameter. Therefore, the results were based on $\mathrm{CD}_{50} / \mathrm{ml}$ of sonic lysate, and the detectable levels of cell-associated cytotoxin were defined as follows: low $\left(2 \times 10^{1}-6 \times 10^{2}\right.$ $\left.C D_{50}\right)$, moderate $\left(10^{3}-10^{4} \mathrm{CD}_{50}\right)$, or high $\left(10^{5}-10^{8} \mathrm{CD}_{50}\right)$.

Nontoxic strains and low-level cytotoxin producers. As shown in table 1,107 strains $(26 \%)$ had no detectable activity, and 262 strains $(63 \%)$ had low levels of cytotoxin in the sonic lysates. Culture supernatants of nontoxic strains and low-level cytotoxin producers had no detectable activity. Low-level cytotoxin producers isolated from humans with hemorrhagic colitis belonged to serotypes O6:H1, O17:H1, O75:H1, O83:H1, O111:NM, O nontypable (NT):NM, and O NT:H NT. Strains isolated from piglets belonged to serogroups $\mathrm{O} 139$ and O141.

Sonic lysates from only 125 of the 262 low-level cytotoxin producers retained HeLa cell activity in the neutralization assays, and 50 had this activity neutralized by antibody to Shiga toxin, including the following: lysates from 18 strains belonging to EPEC serogroups isolated from humans with diarrhea, three ETEC strains, five EIEC strains, six other strains isolated from humans with diarrhea, three strains isolated from humans with hemorrhagic colitis (serotypes O83:H1, O111:NM, O NT:H NT), 12 strains isolated from healthy humans, and three substrains of $E$. coli K12.

Nine strains that were isolated from healthy individuals and that had either no detectable activity or low levels of a nonneutralizable cytotoxin in sonic lysates were retested by the French pressure method of lysis [2]. Although quite cumbersome, this method of bacterial lysis was more efficient than sonication: $95 \%$ of bacterial cells were killed by the French pressure method, whereas only $70 \%$ of cells were killed by sonication. All nine strains showed cytotoxic activity in the French pressure lysates, and one strain did not have this activity neutralized by antibody to Shiga toxin. In general, cytotoxic titers were slightly higher in French pressure lysates than in sonic lysates.

Moderate-level cytotoxin producers. A total of 10 strains $(2 \%)$, isolated from humans or calves with disease, produced moderate levels of a cell-associated cytotoxin (tables 1 and 2). All strains had equal or 10 -fold less $C_{50} / \mathrm{ml}$ of culture supernatant than per $\mathrm{ml}$ of sonic lysate. Cytotoxic activity in sonic lysates and culture supernatants of these strains was not neutralized by antibody to Shiga toxin. The strains isolated from calves had been previously reported as producers of a cytotoxin neutralized by antibody to Shiga toxin [11].

High-level cytotoxin producers. A total of 39 strains $(9 \%)$ produced high levels of cell-associated cytotoxin, and

Table 1. Production of cell-associated cytotoxin by E. coli.

\begin{tabular}{|c|c|c|c|c|c|c|}
\hline \multirow[b]{2}{*}{$\begin{array}{l}\text { Source } \\
\text { of strain }\end{array}$} & \multirow[b]{2}{*}{$\begin{array}{c}\text { Clinical manifestation } \\
\text { of disease }\end{array}$} & \multirow[b]{2}{*}{ Group } & \multicolumn{4}{|c|}{ No. of strains that made } \\
\hline & & & $\begin{array}{l}\text { No detectable } \\
\text { cytotoxin }\end{array}$ & $\begin{array}{l}\text { Low } \\
\text { levels }\end{array}$ & $\begin{array}{l}\text { Moderate } \\
\text { levels }\end{array}$ & $\begin{array}{l}\text { High } \\
\text { levels }\end{array}$ \\
\hline \multirow[t]{10}{*}{ Humans } & Diarrhea & EPEC & 57 & 89 & 0 & 6 \\
\hline & & ETEC & 0 & 9 & 0 & 0 \\
\hline & & EIEC & 0 & 9 & 0 & 0 \\
\hline & & Others & 30 & 35 & 1 & 1 \\
\hline & $\mathrm{HC}^{*}$ & EPEC & 0 & 1 & 0 & 1 \\
\hline & & EHEC & 0 & 0 & 4 & 14 \\
\hline & & Others & 0 & 6 & 0 & 1 \\
\hline & HUS ${ }^{\dagger}$ & EPEC & 0 & 0 & 0 & 3 \\
\hline & & Others & 0 & 0 & 2 & 2 \\
\hline & None & Others & 3 & 44 & 0 & 1 \\
\hline \multirow[t]{2}{*}{ Calves } & Diarrhea & EPEC & 0 & 0 & 0 & 5 \\
\hline & & Others & 0 & 0 & 3 & 4 \\
\hline Piglets & Edema disease & Others & 17 & 64 & 0 & 0 \\
\hline \multirow[t]{2}{*}{ Food } & - & EHEC & 0 & 0 & 0 & 1 \\
\hline & & EIEC & 0 & 1 & 0 & 0 \\
\hline Laboratory (K12) & - & - & 0 & 4 & 0 & 0 \\
\hline Total & & & 107 & 262 & 10 & 39 \\
\hline
\end{tabular}

NOTE. Strains of E. coli were disrupted by sonic lysis, cytotoxic activity of bacterial lysates was detected on HeLa cells, and levels of cytotoxin production were defined by the $\mathrm{CD}_{50} / \mathrm{ml}$ of sonic lysate.

${ }^{*} \mathrm{HC}=$ hemorrhagic colitis.

$\dagger$ HUS $=$ hemolytic uremic syndrome. 
Table 2. Production of elevated levels of cytotoxin(s) by $E$. coli.

\begin{tabular}{|c|c|c|c|c|c|}
\hline \multicolumn{2}{|c|}{ Cytotoxin } & \multirow{2}{*}{$\begin{array}{c}\text { Clinical manifestation } \\
\text { of disease }\end{array}$} & \multicolumn{3}{|c|}{ Serotypes of strains isolated from (no. of strains) } \\
\hline Level & Type & & Humans & Calves & Food \\
\hline \multirow[t]{5}{*}{ Moderate } & II & Diarrhea & O157:H7 (1) & O4:NM (1) & - \\
\hline & & & - & O8:H9 (1) & - \\
\hline & & & - & O149:H8 (1) & - \\
\hline & & $\mathrm{HC}^{*}$ & $\mathrm{O} 157: \mathrm{H} 7$ (4) & - & - \\
\hline & & HUS ${ }^{\dagger}$ & O113:H21 (2) & - & - \\
\hline \multirow[t]{15}{*}{ High } & I & Diarrhea & $\mathrm{O} 26: \mathrm{H} 11(5)$ & O26:H11 (2) & - \\
\hline & & & O111:NM (1) & O111:NM (2) & - \\
\hline & & & $\mathrm{O} 103: \mathrm{H} 2(1)$ & O111:H NT $f(1)$ & - \\
\hline & & & - & O NT:NM (1) & - \\
\hline & & & - & O NT:H4 (2) & - \\
\hline & & & - & $\mathrm{O} 7: \mathrm{H} 40$ (1) & - \\
\hline & & $\mathrm{HC}$ & O157:H7 (1) & - & - \\
\hline & & & O NT:NM (1) & - & - \\
\hline & & HUS & O26:H11 (1) & - & - \\
\hline & & & O111:H8 (1) & - & - \\
\hline & & None & O146:H21 (1) & - & - \\
\hline & I, II & $\mathrm{HC}$ & O111:NM (1) & - & O157:H7 (1) \\
\hline & & & $\mathrm{O} 157: \mathrm{H} 7$ (13) & - & - \\
\hline & & HUS & O111:NM (1) & - & - \\
\hline & & & O157:H7 (2) & - & - \\
\hline Total & & & 36 & 12 & 1 \\
\hline
\end{tabular}

NOTE. Levels of cytotoxin were defined by the $\mathrm{CD}_{50} / \mathrm{ml}$ of bacterial sonic lysate, and the type of cytotoxin was defined as follows: $\mathrm{I}=$ neutralized by antibody to Shiga toxin and II = not neutralized by antibody to Shiga toxin.

* $\mathrm{HC}=$ hemorrhagic colitis.

$\dagger$ HUS = hemolytic uremic syndrome.

$\ddagger \mathrm{NT}=$ nontypable.

only one of these strains was isolated from a healthy individual (tables 1 and 2). All high-level cytotoxin producers had 10-100-fold less $\mathrm{CD}_{50} / \mathrm{ml}$ of culture supernatant than per $\mathrm{ml}$ of sonic lysate. Sonic lysate activity of all strains was neutralized by antibody to Shiga toxin. Supernatant activity of 21 strains was completely neutralized by antibody to Shiga toxin (shown on table 2 as producers of one type of cytotoxin), whereas for 18 strains this activity was either partially neutralized or not neutralized by antibody to Shiga toxin (shown on table 2 as producers of two types of cytotoxin). Two EHEC were isolates from outbreaks of hemorrhagic colitis, and the isolate from food was implicated in one of these outbreaks. Of all the strains belonging to EPEC serogroups, high levels of cytotoxin(s) were detected only in those belonging to serogroups $\mathrm{O} 26$ (8 of 12 strains, serotype $026: \mathrm{H} 11$ ) and O111 (5 of 34 strains, serotype O111:NM; one strain, O111:H8; and one strain, O111:H NT). Two strains of EPEC O26 (H30 and $\mathrm{H} 19)$ have been reported to produce a cytotoxin active on Vero cells [12].

\section{Discussion}

All strains of $E$. coli may make at least small amounts of cell-associated cytotoxin, since some strains with no de- tectable activity in sonic lysates showed cytotoxicity in lysates prepared by the French pressure method. However, the low-level cytotoxicity of some strains was not neutralized by antibody to Shiga toxin. Some strains produced one type of cytotoxin (moderate- and high-level producers), and some strains produced two types of cytotoxin (highlevel producers). All strains of $E$. coli $\mathrm{O} 157: \mathrm{H} 7$ produced elevated levels (moderate or high) of cytotoxin(s).

Cell-associated cytotoxicity not neutralizable by antibody to Shiga toxin has been reported $[2,4]$. Konowalchuk et al. [12] reported that the extracellular cytotoxin of one strain of $E$. coli isolated from an infant with diarrhea (serogroup O128) and one strain isolated from a suckling pig with diarrhea (serogroup O138) was antigenically different from the cytotoxin of $E$. coli strain H30. Smith et al. [13] also detected antigenic variants of "Vero cytotoxin" produced by strains isolated from pigs, and Scotland et al. [14] reported antigenic variation of extracellular cytotoxin from strains of $E$. coli $\mathrm{O} 157$.

Recent studies in our laboratory have shown that EHEC strain 933 produces two cytotoxins that are antigenically distinct but have the same biologic activities and similar genetic determinants as those of Shiga toxin. Antiserum to a crude preparation of the antigenic variant of Shigalike toxin neutralized the cytotoxicity of all 10 moderate- 
level producers, and a mixture of this antiserum and antibody to Shiga toxin completely neutralized the supernatant activity of the other $17 \mathrm{high}$-level producers of two types of cytotoxin described in the present paper [14a]. Studies are in progress to determine whether the nonneutralizable cytotoxin produced at low levels is the same as or different from the antigenic variant of Shiga-like toxin produced by EHEC strain 933.

Elevated levels of cytotoxin(s) were found almost exclusively (48 of 49) in strains of $E$. coli isolated from cases of diarrhea, hemorrhagic colitis or hemolytic uremic syndrome, and food implicated in an outbreak of hemorrhagic colitis. This finding suggests that cytotoxin(s) produced at elevated levels play a role in the pathogenesis of such diseases. All strains isolated from patients with hemolytic uremic syndrome have previously been described as "Vero cytotoxin" producers [15]. Karmali et al. [15] pointed out the marked similarities between hemorrhagic colitis and the colitis seen early in the hemolytic uremic syndrome and suggested that these diseases belong in a spectrum of clinical manifestations of the same underlying process.

Because strains isolated from humans without illness made cytotoxin at much lower levels than did some strains from sources with disease, cytotoxin may be only a virulence determinant for $E$. coli when it is produced in large amounts. Small amounts of cytotoxin, however, could damage host cells if delivered by strains of $E$. coli that adhere avidly to or that invade intestinal epithelial cells. It should also be emphasized that the amount of cytotoxin produced in vitro may not correlate with the amount produced in vivo.

Lilian R. M. Marques, Marjorie A. Moore, Joy G. Wells, I. Kaye Wachsmuth, Alison D. O'Brien Department of Microbiology, Uniformed Services University of the Health Sciences, Bethesda, Maryland; and the Centers for Disease Control, Atlanta, Georgia

\section{References}

1. Levine MM, Edelman R. Enteropathogenic Escherichia coli of classic serotypes associated with infant diarrhea: epidemiology and pathogenesis. Epidemiol Rev 1984;6:31-51

2. O'Brien AD, LaVeck GD, Thompson MR, Formal SB. Produc- tion of Shigella dysenteriae type 1-like cytotoxin by Escherichia coli. J Infect Dis 1982;146:763-9

3. O'Brien AD, Lively TA, Chen ME, Rothman SW, Formal SB. Escherichia coli $\mathrm{O} 157: \mathrm{H} 7$ strains associated with haemorrhagic colitis in the United States produce a Shigella dysenteriae 1 (Shiga) like cytotoxin. Lancet 1983;1:702

4. Cleary TG, Mathewson JJ, Faris E, Pickering LK. Shiga-like cytotoxin production by enteropathogenic Escherichia coli serogroups. Infect Immun 1985;47:335-7

5. O'Brien AD, LaVeck GD. Purification and characterization of a Shigella dysenteriae 1-like toxin produced by Escherichia coli. Infect Immun 1983;40:675-83

6. O'Brien AD, Lively TA, Chang TW, Gorbach SL. Purification of Shigella dysenteriae 1 (Shiga)-like toxin from Escherichia coli $\mathrm{O} 157: \mathrm{H} 7$ strain associated with haemorrhagic colitis. Lancet 1983;2:573

7. Ørskov F, Ørskov I. Serotyping of Escherichia coli. In: Bergan T, ed. Methods in microbiology. Vol 14. New York: Academic Press, 1984:43-112

8. O'Brien AD, LaVeck GD. Immunochemical and cytotoxic activities of Shigella dysenteriae 1 (Shiga) and Shiga-like toxins. Infect Immun 1982;35:1151-4

9. Layne E. Spectrophotometric and turbidimetric methods for measuring proteins. Methods in Enzymology 1957;3:447-54

10. Gentry MK, Dalrymple JM. Quantitative microtiter cytotoxicity assay for Shigella toxin. J Clin Microbiol 1980;12:361-6

11. Sherwood D, Snodgrass DR, O'Brien AD. Shiga-like toxin production from Escherichia coli associated with calf diarrhea. Vet Rec 1985;116:217-8

12. Konowalchuk J, Speirs JI, Stavric S. Vero response to a cytotoxin of Escherichia coli. Infect Immun 1977;18:775-9

13. Smith HW, Green P, Parsell Z. Vero cell toxins in Escherichia coli and related bacteria: transfer by phage and conjugation and toxic action in laboratory animals, chickens and pigs. J Gen Microbiol 1983;129:3121-37

14. Scotland SM, Smith HR, Rowe B. Two distinct toxins active on Vero cells from Escherichia coli O157. Lancet 1985;2:885-6

14a. Strockbine NA, Marques LRM, Newland JW, Smith HW, Holmes RK, O'Brien AD. Two toxin-converting phages from Escherichia coli $\mathrm{O} 157: \mathrm{H} 7$ strain 933 encode antigenically distinct toxins with similar biologic activities. Infect Immun 1986;53 (in press)

15. Karmali MA, Petric M, Lim C, Fleming PC, Arbus GS, Lior $\mathrm{H}$. The association between idiopathic hemolytic uremic syndrome and infection by Verotoxin-producing Escherichia coli. J Infect Dis 1985;151:775-82 